УдК 336.77

\author{
C. М. Халатур, \\ д.ее.н., професор, професор кафедри фінансів, банківської справи та страхування, \\ Аніпровсвкий державний аграрно-економічний університет \\ O. М. Трегуб, \\ студент гр. МгФБСз-1-19, Аніпровський державний аграрно-економічний університет
}

DOI: $10.32702 / 2306-6814.2020 .21-22.37$

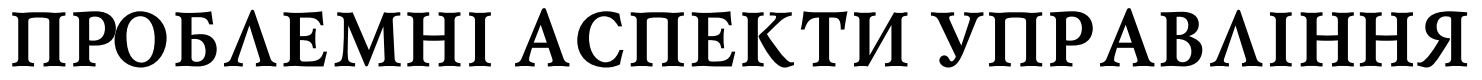 КРЕАИТОСПРОМОЖНІСТЮ ПІАПРИЕМСТВ ТА ПЕРСПЕКТИВИ ÏX РОЗВ' ЯЗАНHЯ
}

\author{
S. Khalatur, \\ Doctor of Economic Sciences Professor,Professor of the Department of Finance, \\ Banking and Insurance, Dnipro State Agrarian and Economic University \\ O. Tregub, \\ Student of gr. MGFBSz-1-19, Dnipro State Agrarian and Economic University
}

\section{PROBLEM ASPECTS OF CREDIT MANAGEMENT OF ENTERPRISES AND THEIR SOLUTION PROSPECTS}

Фінансові ринки суттєво змінилися з часом, завдяки розвиткуінноваційних та складних фінансових інструментів, а також розширенню глобальної діяльності позичальників та кредиторів. Це збільшило роль оцінки кредитоспроможності у потенційному зменшенні будь-якої невизначеності, що виникає внаслідок цього, та сприянні емітентам, інвесторам та регуляторним органам у їх місцевій та глобальній діяльності. Щоб контекстуалізувати це дослідження, необхідно чітко розуміти, що таке кредитоспроможність сільськогосподарського підприємства та чому вона вважається важливою складовою фінансово-господарської діяльності підприємства.

На основі теоретичних прогнозів емпіричні дослідження, що вивчають структуру капіталу сільськогосподарських підприємств, також змогли успішно розкрити деякі факти про структуру капіталу. Найвизначніший фактор, що з'являється в ході досліджень, загалом може бути синтезований або в теорію компромісу, або в теорію замовлень (тобто розмір підприємства, можливості її зростання та прибутковість тощо). Однак останніми роками дедалі ширше визнається, що такі теорії не повністю пояснюють поведінку сільськогосподарських підприємств щодо їх рішень стосовно фінансової структури. Виявляється, що більшість сільськогосподарських підприємств з низьким ризиком парадоксально віддають перевагу низькому рівню підготовки, незважаючи на той факт, що такі підприємства можуть легко отримати доступ до боргових ринків, не посилюючи потенційний ризик банкрутства.

В оцінці сільськогосподарських кредитів у цьому дослідженні використовуються: багатоперіодна імітаційна модель, яка ендогенізує рішення щодо інвестицій у сільськогосподарські підприємства, оцінки кредитів та ціноутворення на позику на основі процедур визначення кредитоспроможності сільськогосподарського підприємства. Результати моделі нададуть можливість оцінити за кредитними цінами часові структурні показники діяльності, кредитні класифікації та процентні ставки, паралельні напрямки інвестиційної діяльності підприємства, фінансування та обслуговування боргу. Більше того, ціна позикодавця гасить стимули до зростання, оскільки кредитоспроможність зменшується. 
Financial markets have changed significantly over time, thanks to the development of innovative and sophisticated financial instruments, as well as the expansion of global activities of borrowers and lenders. This has increased the role of credit assessment in potentially reducing any resulting uncertainty and assisting issuers, investors and regulators in their local and global operations. To contextualize this study, it is necessary to clearly understand what the creditworthiness of an agricultural enterprise is and why it is considered an important component of financial and economic activities of the enterprise.

Based on theoretical predictions, empirical studies studying the capital structure of agricultural enterprises have also been able to successfully reveal some facts about the capital structure. The most significant factor that emerges in research can generally be synthesized into either compromise theory or order theory (ie, enterprise size, growth potential, and profitability, etc.). However, in recent years it has become increasingly recognized that such theories do not fully explain the behavior of agricultural enterprises in their decisions regarding financial structure. It turns out that most lowrisk agricultural enterprises paradoxically prefer a low level of training, despite the fact that such enterprises can easily gain access to debt markets without increasing the potential risk of bankruptcy.

In the evaluation of agricultural loans in this study uses: multi-period simulation model, which endogenizes the decision to invest in agricultural enterprises, credit assessments and loan pricing based on the procedures for determining the creditworthiness of an agricultural enterprise. The results of the model will provide an opportunity to assess at credit prices time structural performance indicators, credit classifications and interest rates, parallel areas of investment activity of the enterprise, debt financing and servicing. Moreover, the lender's price dampens growth incentives as creditworthiness declines.

Ключові слоВа: кредит, чіна позики, результати діяльності, сільськогосподарське підприємство. Key words: credit, loan price, results of activity, agricultural enterprise.

\section{ВСТУП}

Сукупні наслідки фрінансово-господарської діяльності в сільському господарстві, дерегуляція процентних ставок у сорері фрінансових ринків та покращена системна інформація для кредиторів принесли значні зміни в кредитній оцінці, оцінці ризику та ціновій політиці у кредитуванні сільського господарства. Оцінка позики на рівні клієнта отримує більший акцент та все більше ціноутворення на позики враховує характеристики ризику індивідуальних сільськогосподарських підприємств. Це стало звичним,спостерігати за позикодавцями, які класифікують позичальників на кілька класів ризику з вищими процентними ставками, пов'язаними з вищими класами ризику. Ці зміни в обсязі оцінки ризику та в фрормі відповіді позикодавця надають нові установки для кредитної оцінки позикодавця - умови фрінансування та результати діяльності позичальника.

\section{META CTATTI}

Мета статті - визначити та оцінити зв'язок між бізнесом у часі, результатами діяльності та умовами фінансування за допомогою підходу моделювання, який ендогенізує рішення щодо інвестицій сільськогосподарських підприємств, оцінки кредитів, ціноутворення на основі процедур кредитного оцінювання комерційних кредиторів.

\section{ВИК ААА ОСНОВНИХ РЕЗУ АЬТАТІВ AOC $\triangle$ IАЖЕНHЯ}

Необхідно розробити багатоперіодну модель для оцінки зв'язків та репрезентативної ситуації на окремому сільськогосподарському підприємстві за альтернативними інвестиційними стратегіями, економічними умовами, і початковими фрінансовими позиціями, описати підхід до моделювання, а також розглянути наслідки для фрінансування сільського господарства.

Попередні дослідження концепцій кредитування та процедур оцінки кредитних відносин у сільському господарстві показали, що відповіді кредиторів з урахуванням характеристик бізнесу та управлінських дій сільськогосподарських підприємств впливають на загальна вартість запозичень цих підприємств через сукупний вплив процентної ставки на позики та ліквідність, що відображає суб'єктивну оцінку кредиту позичальника та утримується в резерві як джерело ліквідності. У свою чергу наслідки цих витрат можуть вплинути на оптимальну фрінансову структуру (леверидж) та темпи зростання фрінансово-господарської діяльності сільськогосподарського підприємства, а також склад його активів, управління ризиками та інші види діяльності, що приносять дохід.

Основними кроками є: виявити ключові змінні, які найкраще визначають кредитоспроможність сільськогосподарських підприємств, вибрати відповідні заходи 


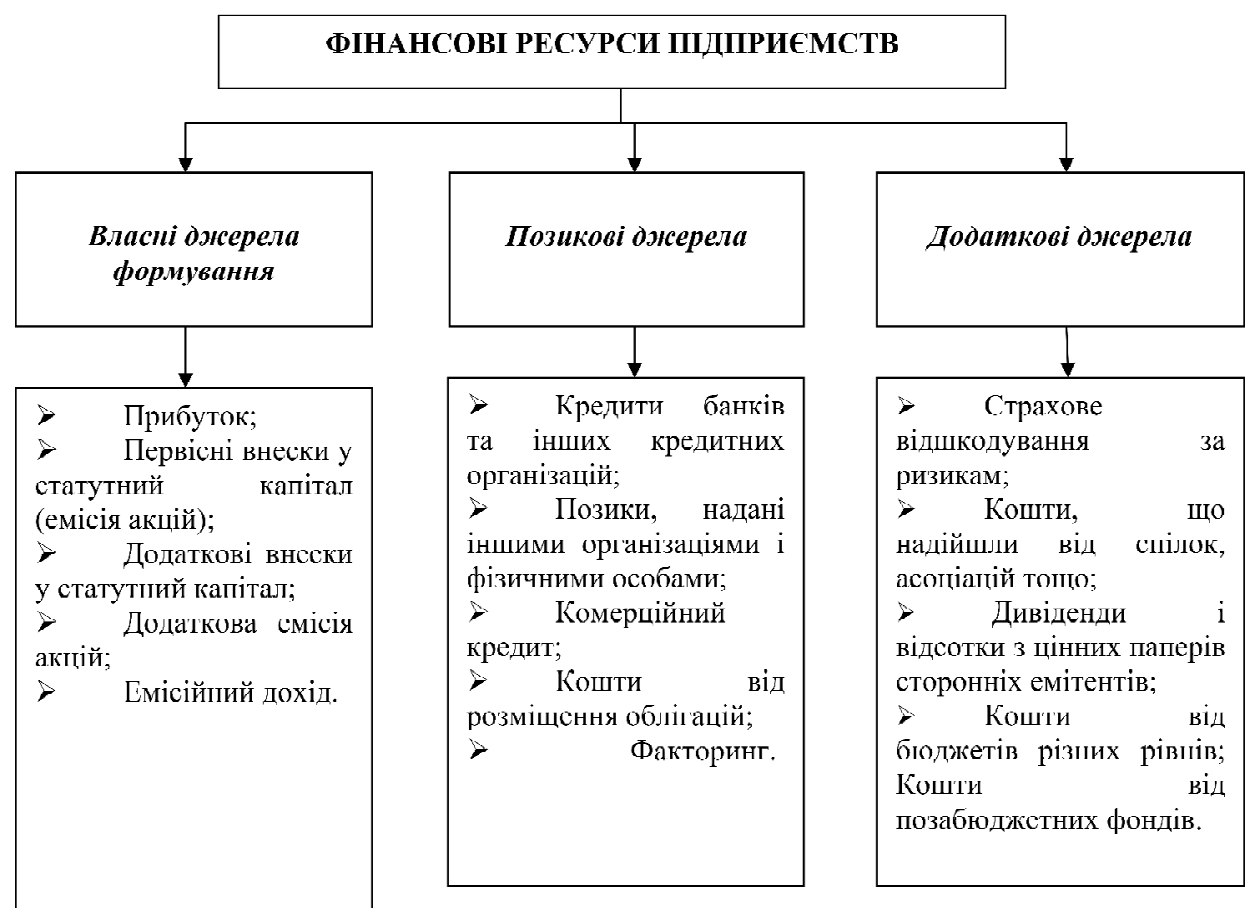

Рис. 1. Джерела формування фінансових ресурсів підприємства

для цих змінних, зважити змінні відповідно до їх відносного значення для позикодавця, а потім оцінити кожну позику як середньозважене значення відповідної змінної. Тоді результати оцінки кредитоспроможності можуть служити основою для позики з коригуванням ризику ціноутворення, а також для оцінки якості кредитних портоелів, що підтверджують рішення про позику іншого кредитного персоналу та регуляторів.
До фрінансових ресурсів сільськогосподарського підприємства можна віднести залучений і власний капітал у грошовій формі, фонди коштів акумуляційного характеру, прибутки від реалізації товарів та інше. Узагальнена класифрікація фрінансових ресурсів сільськогосподарського підприємства зображена на рисунку 1.

Таким чином, необхідно, щоб дослідження інтегрувало багатоперіодний аналіз ефективності фрінансово-

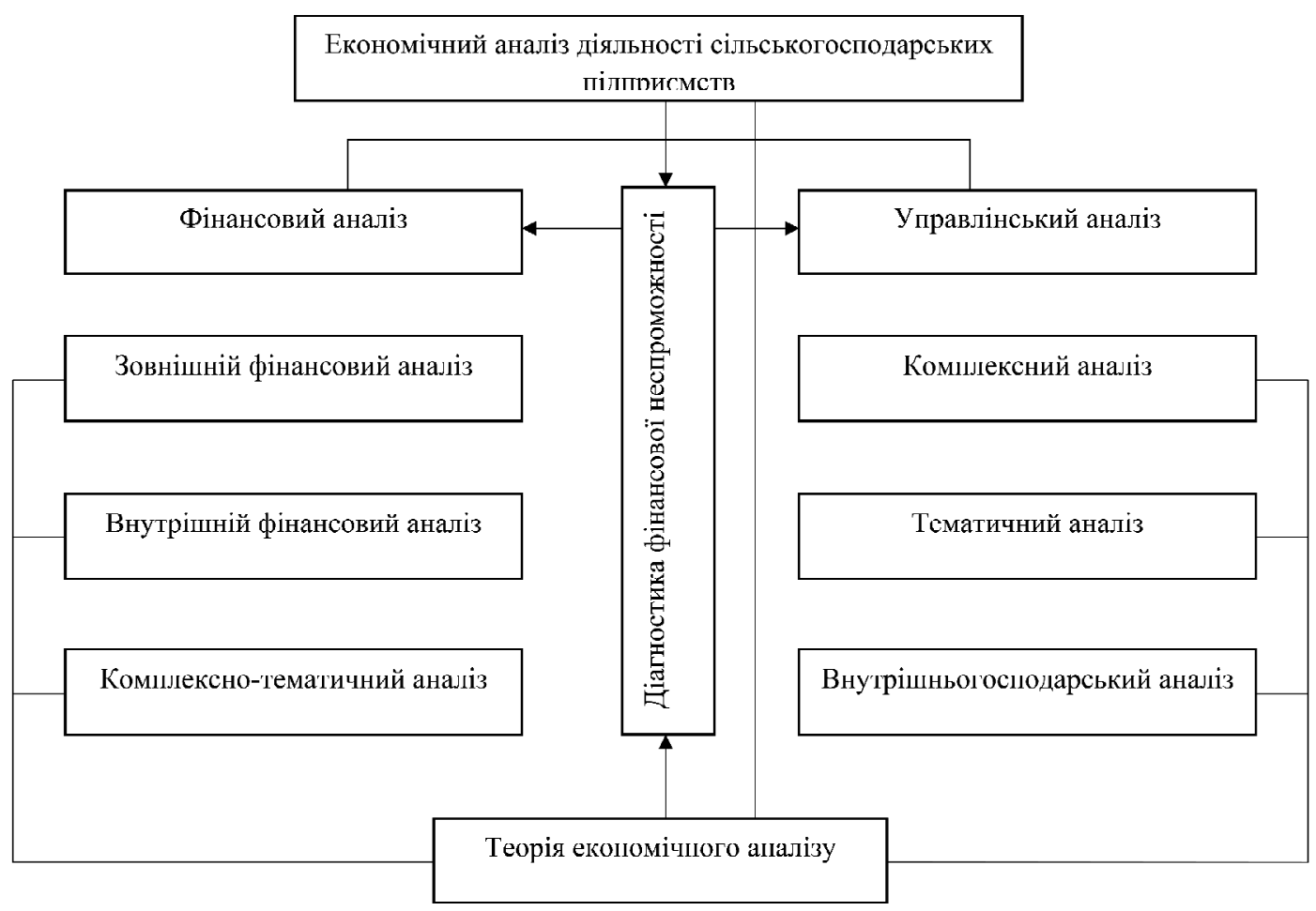

Рис. 2. Структура економічного аналізу і діагностики фінансових можливостей сільськогосподарського підприємства 
господарської діяльності сільськогосподарського підприємства з методами позикодавця щодо позикових цін, де ціна позики базується на результатах кредитної оцінки цього підприємства, щоб оцінити їх спільні наслідки. Це дослідження зосереджується на спільній оцінці цих відносин під передумовою, що такий підхід дасть більше обгрунтованих прогнозів майбутньої ефективності та фінансового стану сільськогосподарських підприємств, враховуючи більше використання коригування у ціноутворенні позик кредиторами як відповідь на зміни кредитоспроможності позичальника.

Узагальнюючи наведені вище вимоги до формування і використання фінансових ресурсів сільськогосподарського підприємства можна окреслити загальні види і джерела надходжень грошових фінансових ресурсів і напрями їх спрямування (рис. 2).

Далі розглянемо концепцію моделювання. Щоб проілюструвати зв'язок між результатами фрінансово-господарської діяльності сільськогосподарського підприємства та ціноутворенням на позику, спочатку необхідно абстрагуватися від деталей ризику і часу за допомогою простої моделі рентабельності, в якій норма прибутку позичальника на власний капітал виражається як середньозважена величина різниці між рентабельністю активів (ra) та вартості боргу (i), де ваги - це відношення активів до власного капіталу (A / E) і заборгованість перед власним капіталом (D / E), відповідно, і показник прибутковості вираховується за даними для оподаткування (t) та споживання (c):

$r=[\mathrm{ra}(A / E)-i(D / E)](-t)(1-c)$.

У свою чергу процентна ставка за кредитом $€$ функцією вартості позикодавця на придбання позикових коштів (if), постійні витрати на управління позикою (ia) та віднесена премія за ризик (i,) до кредитоспроможності та відповідного кредитування витрати окремих позичальників:

$i=f($ if $i a, 0)$.

Якщо припустити, що позикодавець використовує підхід "пул коштів" до фрінансування індивідуальних позик і розподіляє між позичальниками постійні витрати на позику пропорційно обсягу їх позик, які характерні для сільськогосподарського кредитування - тоді різниця в процентних ставках серед позичальників зумовлена насамперед відмінностями у кредитоспроможності. Більше того, якщо кредитоспроможність оцінюється на основі систематичної, послідовної процедури кредитного скорингу, тоді диференціальна премія за ризик (i, ) фрункцією змінних та ваг, що складають кредитний бал. Це $\epsilon$, ir $=f(C R E D I T$ SCORE) у якому

CREDIT SCORE $=f(a X " a 2 X 2, \ldots, a X)$,

де $\mathrm{Xn}$ - набір змінних кредитоспроможності,

a $a_{n}-$ набір ваг змінних.

Для ілюстрації аналітичних ефектів диференціала ціноутворення на фрінансову структуру позичальника, припустимо, що кредитна оцінка (i, отже, ставка позики) $є$ функцією лише однієї змінної, позиція кредитного плеча позичальника, яка вимірюється за співвідношенням боргу до власного капіталу (D / E). Більше того, нехай відношення буде лінійною функцією так, що $i=$ ifa $+b(D / E)$, де ifa - визначена базова ставка за рахунок фінансування та адміністративних витрат i b реакція ставки на збільшення кредитного плеча на одну одиницю. Підставивши $i=$ ifa $+b(D / E) m a A / E=$ $D I E+1$ у рівняння (1), розширення термінів та видалення споживання і прибутковості податкових складових

$r,=[r a(D / E)+r a-i a(D / E)-b(D / E) 2]$.

Якщо метою $€$ максимізація повторного кредитування шляхом визначення D / E як змінної рішення, потім диференціювання (5) щодо DIE, прирівнюючи результат до нуля, а рішення для DIE дає оптимальне кредитне плече (D / E r-a fa).

Тоді оптимальні важелі позитивно пов'язані зі змінами прибутковості активів і негативно пов'язані зі змінами базової ставки та параметрів важеля. На відміну від них, традиційні рамки, які не мають диференційованих цін на основі кредитного підрахунку балів, дозволяють максимізувати (1) за умови недорогого обмеження, накладеного позикодавцем на максимальному DIE. Без врахування ризику або інших нелінійностей у поверненнях або витрат на позики, максимізація (I) дотягнула б важелі до межі.

На практиці, кредитний бал зазвичай базується на декількох змінних, ваги яких різняться серед кредиторів. Основні змінні, що визначають кредитоспроможність, як правило, включають прибутковість, ліквідність, платоспроможність позичальника, позицію застави та можливість погашення. Точні ваги - це емпіричне питання, яке може різнитися серед кредиторів. Однак характеристики кредитних контрактів, що передбачають необхідне погашення основної суми позики та фріксованих відсотків зобов'язання, як правило, пропонують кредиторам більше підкреслить безпеку та повернення позики, ніж очікувану прибутковість позичальника, оскільки позикодавець не бере участі безпосередньо в прибутках позичальника.

Нарешті, тенденція кредиторів до групування своїх позичальників на кілька дискретних класів для ціноутворення, оцінка кредиту та моніторинг призводять до того, що кредитний рейтинг і ризик премії стають дискретними та мають змінні звичайного рейтингу. Таким чином,

$$
\begin{aligned}
& \text { /i, якщо CREDIT SCORE > CS } \\
& i, .=i \text {, якщо CS } 2<\text { CREDIT SCORE < CS, } \\
& r n \text { якщо CS, < CREDIT SCORE < CSn, }
\end{aligned}
$$

де CSn позначає граничний показник між різними кредитними класами.

Суттєвою особливістю цих змінних є взаємозв'язки, що виникають з часом серед результатів діяльності, кредитної оцінки та ціноутворення на позики. Так, кредитна оцінка (а отже, ставка позики) повинна залежати як від поточного фрінансового стану та прогнозованих результатів фінансово-господарської діяльності сільськогосподарського підприємства.

Крім того, з часом кредитна оцінка буде змінюватися в міру того, як відбудуться зміни в поточній та прогнозованій ефективності, деякі з яких $є$ запланованими змінами, тоді як інші $€$ результатом ефекту непередбачуваних випадкових факторів. Однак моделювання таких одночасних і динамічних відносин давали б дуже складні системи, які також підпорядковуються якості прогнозів. Більше того, кредитори самі не дотягують до цього рівня ефективності діяльності, тому що більша частина їх заслуг при оцінці та моделюванні кредитно- 
го балу базуються на даних про минуле позичальника і його теперішній фрінансовий стан, а не довгострокові прогнози фрінансових результатів.

Коли використовуються проєкції, здебільшого вони відображають очікувані результати протягом одного року або постійні рівні діяльності сільськогосподарських підприємств та процентні ставки протягом довших періодів часу. Таким чином, тимчасові відносини між кредитним балом, ціноутворенням на позику та результатами фінансово-господарської діяльності сільськогосподарського підприємства може бути правдоподібно змодельовані в рекурсивних рамках, в яких рішення позикодавця щодо кредитування, що впливають на майбутні терміни фінансування позичальника базуються на поточному рівні фрінансового стану сільськогосподарського підприємства, який у свою чергу визначається за минулими показниками. Тобто кредитор обгрунтовує рішення щодо кредитування на очікуваних результатах у контексті поточного стану та фрінансової структури сільськогосподарського підприємства, яка сама базується на минулому досвіді.

Керівникам сільськогосподарських підприємств необхідно переглядати наступні пункти, оцінюючи різні позики. Перш ніж оцінювати конкретні умови позик, необхідно продумати цілі та напрямки розвитку сільськогосподарського підприємства та прагнути вибрати такий пакет позик, який ефективний, а також той, який відповідає бізнес-цілям фрінансово-господарської діяльності. Керівник сільськогосподарського підприємства повинен розуміти умови та ризики окремих альтернативних позик. Оскільки позикодавці розробили різні терміни надання позик для задоволення потреб своїх клієнтів, керівнику сільськогосподарського підприємства слід враховувати ті умови кредитування, які відповідають його цілям та відповідають рівню толерантності до ризику.

1. Передусім, необхідно розуміти свої зобов'язання та обов'язки перед підписанням договору та інших документів, пов'язаних із кредитною операцією.

2. Знати загальну вартість усіх зборів, що підлягають сплаті при отриманні позики та щороку.

3. Переглянути, що означає невиконання кредиту та що може прискорити попит банку на оплату. Якщо це буде зроблено, як це вплине на діяльність сільськогосподарського підприємства?

4. Визначити вид виплати позики. Чи буде повністю сплачена позика в термін погашення? Кредитор не зобов'язаний продовжувати. Необхідно розглянути доступні варіанти, якщо позика не продовжується.

5. Отримати приблизний графрік виплат за позикою та спроектувати свою здатність виконувати виплати за позикою. Визначити місяці року, які були б кращими для виплат за кредитом. Крім того, слід враховувати різні строки погашення позики, щоб розробити суму платежу, яка відповідає можливості погашення. Чи є у позики гнучкі умови? Чи можливо відкласти виплату основної суми через різні вимоги щодо ризику?

6. Чи є процентна ставка фріксованою, змінною чи регульованою? Які виплати за вищими процентними ставками?

7. Якщо позика має змінну або регульовану процентну ставку, дізнатися про індекс, маржу, період коригу- вання та обмеження. Розглянути історичні закономірності та рівні основних ставок банку та визначите свою здатність сплачувати боргові виплати у разі зростання процентних ставок.

8. Запитати про штрафри за передоплату. Як це впливає на вартість рефрінансування?

9. Запитати про пільгу на передоплату? Чи можна здійснити додаткову виплату основної суми протягом року? Чи містять умови позики щорічну пільгу щодо передплати? Який відсоток від початкового виплаченого залишку?

10. Запитати про вимоги щодо звітності? Які варіанти конверсії позики доступні? Термін позики відкритий чи закритий?

11. Зрозуміти наслідки затримки платежів. Крім того, розуміти процедури стягнення майна, зобов'язання щодо забезпечення та всі права позичальника. Чи існують збори за управління позиками, спричинені затримкою платежів.

12. Враховувати інші фрактори, зокрема попередній досвід роботи з позикодавцем та кредитною установою, загальний досвід сільськогосподарської діяльності позикодавця та знання позикодавця про діяльність даного сільськогосподарського підприємства.

\section{ВИСНОВКИ ТА ПЕРСПЕКТИВИ ПОАА ЬШИХ АОС ІІАЖЕНЬ}

У нинішніх ризикованих економічних умовах управління кредитоспроможністю сільськогосподарського підприємства повинно здійснюватися так само ретельно, як і інші виробничі процеси. Як і насіння та хімікати, варіанти сільськогосподарського кредитування змінюються та розширюються новими та інноваційними продуктами і можуть ускладнюватися юридичними проблемами. Позичальникам пропонується більше альтернатив, і їм потрібно розробити процедури оцінки такого вибору. Ці альтернативи дають позичальникам можливість краще управляти своїми фрінансовими справами.

У цьому дослідженні викладено практичний підхід до оцінки позик. Позичальник починає з встановлення коротко- та довгострокових фінансових цілей для фінансово-господарської діяльності. Тоді позичальник повинен розуміти можливості обслуговування боргу у своєму господарському бізнесі та здатність сільськогосподарського підприємства обслуговувати цей борг. Щоб оцінити кредитні варіанти, позичальник повинен розуміти всі положення та зобов'язання та знати, що процентна ставка - не єдине питання. Умови будуть впливати на те, як позичальник керуватиме своїм фрінансовим ризиком. Позичальник повинен відповідати рівням невизначеності або мати положення, що зменшують невизначеність, щоб відповідати його толерантності до ризику. Позичальник повинен бути впевнений, що кредитний договір буде відповідати його цілям, і повинен періодично переглядати свої кредитні договори, щоб не відставати від цих цілей.

Напрямом подальших досліджень визначено оптимізацію можливості моделювати фрінансові показники, інвестиційні структури, та фрінансування діяльності, яка виникає в результаті зусилля сільськогосподарського підприємства протистояти обмеженню його ресурсів та 
експлуатаційні вимоги з метою максимізації встановлених цілей.

\section{Література:}

1. Adzobu L.D., Agbloyor E.K., \& Aboagye A. (2017). The effect of loan portfolio diversification on banks' risks and return Evidence from an emerging market. Managerial Finance, 43 (11). 1274-1291. Retrieved from http:// ugspace.ug.edu.gh/handle/123456789/22471

2. Abid L., Ouertani A.N., \& Zouari-Ghorbel N. (2014). Macroeconomic and Bank-specific Determinants of Household's Non-Performing Loans in Tunisia: A Dynamic Panel Data. Procedia Economics and Finance. 13, 58-68. https://doi.org/10.1016/S2212-5671(14)00430-4

3. Beck T. (2012). The role of finance in economic development: benefits, risks, and politics. Oxford Handbook of Capitalism, 161-203. https://doi.org/ 10.1093/oxfordhb/9780195391176.013.0007

4. Kamran H.W., Haseeb M., Nguyen V.C., \& Nguyen T.T. (2020). Climate change and bank stability: The moderating role of green financing and renewable energy consumption in ASEAN. Talent Development and Excellence, 12 (2s). 3738-3751. https://doi.org/ 10.31219 /osf.io/v48fa

5. Khalatur S. M. Innovative doctrine development of agriculture growth of Ukraine / S. М. Khalatur / / Технологічний аудит та резерви виробництва. - 2017. - № 4/5 (35). - C. 19-26.

6. Khalatur S., Zhylenko K., Masiuk Y., Velychko L., Kravchenko M. (2018). Assessment of bank lending diversification in the national economy of Ukraine. Banks and banks systems. Vol. 13 (3). P. 141-150.

7. Khalatur S., Zenon Stachowiak, Kateryna Zhylenko, Oksana Honcharenko and Oleksandr Khalatur (2019). Financial instruments and innovations in business environment: European countries and Ukraine. Investment Management and Financial Innovations. 16 (3), 275-291.

8. Khalatur S., Khaminich S., Budko O., Dubovych O., Karamushka O. (2020). Multiple system of innovation investment decisions adoption with synergetic approach usage. Entrepreneurship and Sustainability. Vol. 7. Num. 4, 2745-2763. http://doi.org/10.9770/jesi.2020.7.4(12).

9. Messai A.S., \& Jouini F. (2013). Micro and macro determinants of non-performing loans, International Journal of Economics and Financial Issues. 3 (4), 85-860. Retrieved from https://www.econjournals.com/index.php/ijefi/article/view/517/pdf

10. Najib H.S. Farhan, Mosab I. Tabash and Mohammad Yameen (2020). The relationship between credit policy and firms' profitability: empirical evidence from Indian pharmaceutical sector. Investment Management and Financial Innovations. 17 (2), 146-156. doi:10.21511/ imfi.17(2).2020.12

12. Oluwaseyi Olalere, Md. Aminul Islam, Mohd Zukime Mat Junoh, Wan Sallha Yusoff and Mohammed Masum lqbal (2020). Revisiting the impact of intrinsic financial risks on the firm value of banks in ASEAN-5 countries: a panel data approach. Banks and Bank Systems, 15 (2), 200-213. doi:10.21511/bbs.15(2).2020.18

13. Yevhenii Zolotukhin (2018). Creditworthiness assessment of municipalities in Ukraine. Development Management, 16 (3). 51-60.
References:

1. Adzobu, L. D. Agbloyor, E. K. and Aboagye, A. (2017), "The effect of loan portfolio diversification on banks' risks and return Evidence from an emerging market", Managerial Finance, vol. 43(11), pp. 1274-1291, available at: http:/ /ugspace.ug.edu.gh/handle/123456789/22471 (Accessed 30 Oct 2020).

2. Abid, L. Ouertani, A. N. and Zouari-Ghorbel, N. (2014), "Macroeconomic and Bank-specific Determinants of Household's Non-Performing Loans in Tunisia: A Dynamic Panel Data", Procedia Economics and Finance, vol. 13, pp. 58-68. https://doi.org/10.1016/S2212$5671(14) 00430-4$

3. Beck, T. (2012), "The role of finance in economic development: benefits, risks, and politics", Oxford Handbook of Capitalism, pp. 161-203. https://doi.org/ 10.1093/oxfordhb/9780195391176.013.0007

4. Kamran, H. W. Haseeb, M. Nguyen, V. C. and Nguyen, T. T. (2020), "Climate change and bank stability: The moderating role of green financing and renewable energy consumption in ASEAN", Talent Development and Excellence, vol. 12(2s), pp. 3738-3751. https://doi.org/ $10.31219 /$ osf.io/v48fa

5. Khalatur, S. M. (2017), "Innovative doctrine development of agriculture growth of Ukraine", Tekhnolohichnyj audyt ta rezervy vyrobnytstva, vol. 4/5 (35), pp. 19-26.

6. Khalatur, S. Zhylenko, K. Masiuk, Y. Velychko, L. and Kravchenko, M. (2018), "Assessment of bank lending diversification in the national economy of Ukraine", Banks and banks systems, Vol. 13(3), pp. 141-150.

7. Khalatur, S. Stachowiak, Z. Zhylenko, K. Honcharenko, O. and Khalatur, O. (2019), "Financial instruments and innovations in business environment: European countries and Ukraine", Investment Management and Financial Innovations, vol. 16 (3), pp. 275-291.

8. Khalatur, S. Khaminich, S. Budko, O. Dubovych, O. and Karamushka, O. (2020), "Multiple system of innovation investment decisions adoption with synergetic approach usage", Entrepreneurship and Sustainability, Vol. 7, no. 4, pp. 2745-2763. http://doi.org/10.9770/jesi.2020.7.4(12).

9. Messai, A. S. and Jouini, F. (2013), "Micro and macro determinants of non-performing loans", International Journal of Economics and Financial Issues, vol. 3(4), pp. 85-860, available at: https://www.econjournals.com / index.php/ijefi/article/view/517/pdf (Accessed 30 Oct 2020).

10. Farhan, N. H.S. Tabash, M. I. and Yameen, M. (2020), "The relationship between credit policy and firms' profitability: empirical evidence from Indian pharmaceutical sector", Investment Management and Financial Innovations, vol. 17(2), pp. 146-156. doi:10.21511/imfi.17(2).2020.12

12. Oluwaseyi Olalere, Md. Aminul Islam, Mohd Zukime Mat Junoh, Wan Sallha Yusoff and Mohammed Masum lqbal (2020), "Revisiting the impact of intrinsic financial risks on the firm value of banks in ASEAN-5 countries: a panel data approach", Banks and Bank Systems, vol. 15 (2), pp. 200-213. doi:10.21511/bbs.15(2).2020.18

13. Zolotukhin, Ye. (2018), "Creditworthiness assessment of municipalities in Ukraine", Development Management, vol. $16(3)$, pp. 51-60.

Стаття надійшла до редакиії 13.11.2020р. 